\title{
Изменения популяционных систем зеленых лягушек (Pelophylax esculentus complex) на территории Русской равнины
}

\author{
Г.А. Лада \\ Тамбовский государственный университет имени Г.Р. Державина, \\ Россия, 392000, г. Тамбов, ул. Интернациональная, 33 \\ E-mail: esculenta@mail.ru
}

\begin{abstract}
Аннотация. Цель работы - изучение популяционных систем среднеевропейских зеленых лягушек (Pelophylax esculentus complex) и их динамики в пределах Русской равнины. Многолетние (от 14 до 39 лет) полевые исследования позволили выявить в ряде мест изменения типов популяционных систем. Отмечен переход популяционных систем от $L E$-типа к $R E L$-типу, а также от $E$-типа к $R E$ типу. Основная причина - высокая способность к расселению озерной лягушки, Pelophylax ridibundus. Используя речные русла или естественные понижения рельефа с повышенной влажностью местообитаний, особи этого вида активно проникают в лесные массивы, в которых заселяют непроточные или слабопроточные водоемы естественного или антропогенного происхождения. В ряде случаев этому способствуют изреживание лесных массивов в результате интенсивных лесозаготовительных работ и появление новых водоемов на пути естественного расселения молодняка амфибий.
\end{abstract}

Ключевые слова: Pelophylax ridibundus, Pelophylax lessonae, Pelophylax esculentus, озерная лягушка, прудовая лягушка, съедобная лягушка.

Для цитирования: Лада Г.А. 2021. Изменения популяционных систем зеленых лягушек (Pelophylax esculentus complex) на территории Русской равнины. Полевой журнал биолога, 3 (1): 53-63. DOI: 10.52575/2658-3453-2021-3-1-53-63

\section{Dynamics of Population Systems of Green Frogs (Pelophylax esculentus complex) on the Territory of the Russian Plain}

\author{
Georgiy A. Lada \\ Derzhavin Tambov State University, \\ 33 Internatsionalnaya St, Tambov, 392000, Russian Federation \\ E-mail: esculenta@mail.ru
}

\begin{abstract}
The purpose of the work is to study the population systems of the central European green frogs (Pelophylax esculentus complex) and their dynamics within the Russian Plain. The population systems of green frogs are combinations of two parent species (the marsh frog, Pelophylax ridibundus, and the pond frog, $P$. lessonae) and their hemiclonal hybrid (the edible frog, $P$. esculentus) in concrete places. In general, all seven possible types of population systems were found in the Russian Plain: three variants of "pure" populations $(R-, L-$, and $E$-type) and four variants of mixed population systems $(R E-, L E-, R L-$, and $R E L$-type). Long-term (from 14 to 39 years) field studies have revealed changes in the types of population systems in a number of places. There is a transition of population systems from $L E$-type to $R E L$-type, or (outside the range of $P$. lessonae) from $E$-type to $R E$-type. The main reason for this is the high dispersal capacity of the lake frog, $P$. ridibundus. Using riverbeds or natural relief depressions with high humidity of habitats, individuals of this species actively penetrate into woodlands, in which they inhabit nonflowing or low-flowing reservoirs of natural or anthropogenic origin (typical biotopes of P. lessonae and
\end{abstract}


$P$. esculentus, which often lives together with it). In some cases, this is facilitated by changing environmental conditions: sparseness of woodlands as a result of intensive logging operations and the emergence of new reservoirs on the route of young amphibians.

Key words: Pelophylax ridibundus, Pelophylax lessonae, Pelophylax esculentus, marsh frog, pond frog, edible frog.

For citation: Lada G.A. 2021. Dynamics of Population Systems of Green Frogs (Pelophylax esculentus complex) on the Territory of the Russian Plain. Field Biologist Journal, 3 (1): 53-63. (In Russian.) DOI: $10.52575 / 2658-3453-2021-3-1-53-63$

\section{Введение}

К комплексу среднеевропейских водных, или зеленых лягушек (Pelophylax esculentus complex), относятся три вида - съедобная лягушка, Pelophylax esculentus (Linnaeus, 1758), озерная лягушка, Pelophylax ridibundus (Pallas, 1771), и прудовая лягушка, Pelophylax lessonae (Camerano, 1882). Первая из них (P. esculentus) имеет гибридную природу и происходит от двух других, родительских видов (P. ridibundus и P. lessonae) [Berger, 1967, 1968]. Обитая симпатрично на протяжении бо́льшей части своих ареалов, три этих вида встречаются в конкретных местообитаниях в различных сочетаниях, образуя так называемые популяционные системы [Günther, 1975]. Согласно общепринятой классификации [Uzzell, Berger, 1975], выделяют семь типов популяционных систем зеленых лягушек, которые условно обозначаются сочетанием первых букв их видовых названий. Три из них это «чистые» популяции трех видов (популяционные системы $R-, L-$, и $E$-типа), остальные четыре типа - это смешанные популяционные системы, представляющие собой различные комбинации, состоящие из двух $(R E-, L E-, R L$-тип) или всех трех (REL-тип) видов комплекса. K важным характеристикам популяционной системы зеленых лягушек относятся численность образующих ее видов, а также плоидность и пол особей P. esculentus. Последняя может быть представлена диплоидными (2n), триплоидными (3n) и даже тетраплоидными (4n) экземплярами, обоими полами, только самцами или только самками [Tunner, 1974; Цауне, Боркин, 1993; Berger et al., 1998; Morozov-Leonov et al., 2003; Borkin et al., 2004, 2006; Боркин и др., 2005; Лада и др., 2011б; Biriuk et al., 2016].

Нами в пределах Русской равнины найдены все семь типов популяционных систем, изучены их встречаемость и особенности географического распределения [Lada et al., 1995; Лада, 1998, 2001; Lada, 1999; Боркин и др., 2003, 2005, 2008; Borkin et al., 2004, 2006; Ручин и др., 2005; Лада и др., 2009, 2011a, б; Biriuk et al., 2016]. В статье изложены и проанализированы сведения, свидетельствующие об изменениях типов популяционных систем зеленых лягушек в ряде мест Русской равнины.

\section{Материал и методы исследования}

В целом полевые исследования комплекса зеленых лягушек, в том числе и образуемых ими популяционных систем, проведены в 1982-2020 годы, они охватили 33 административных региона России, Украины, Белоруссии и Молдавии в пределах Русской равнины.

Видовая идентификация лягушек осуществлялась методом проточной ДНКцитометрии по размеру генома [Боркин и др., 1987; Vinogradov et al., 1990]. Дополнительными диагностическими показателями служили внешние морфологические (относительные размеры и форма внутреннего пяточного бугорка и относительные размеры голени) и биоакустические (особенности брачных сигналов самцов) признаки [Лада, 1995].

В целом ряде изученных локалитетов популяционные системы зеленых лягушек находились под нашим наблюдением в течение длительного времени (от 14 до 39 лет). Это позволило выявить несколько случаев их изменения, то есть перехода от одного типа популяционной системы к другому. 


\section{Результаты и их обсуждение}

Изменения типов популяционных систем зеленых лягушек выявлены нами в следующих местах.

1. Тамбовская область, окрестности г. Тамбов, озеро Святовское (рис. 1). Это озеро располагается в Цнинском лесном массиве, на расстоянии примерно 2 км от его западной опушки, и соединяется с руслом реки Цна небольшим ручьем (рис. 2).

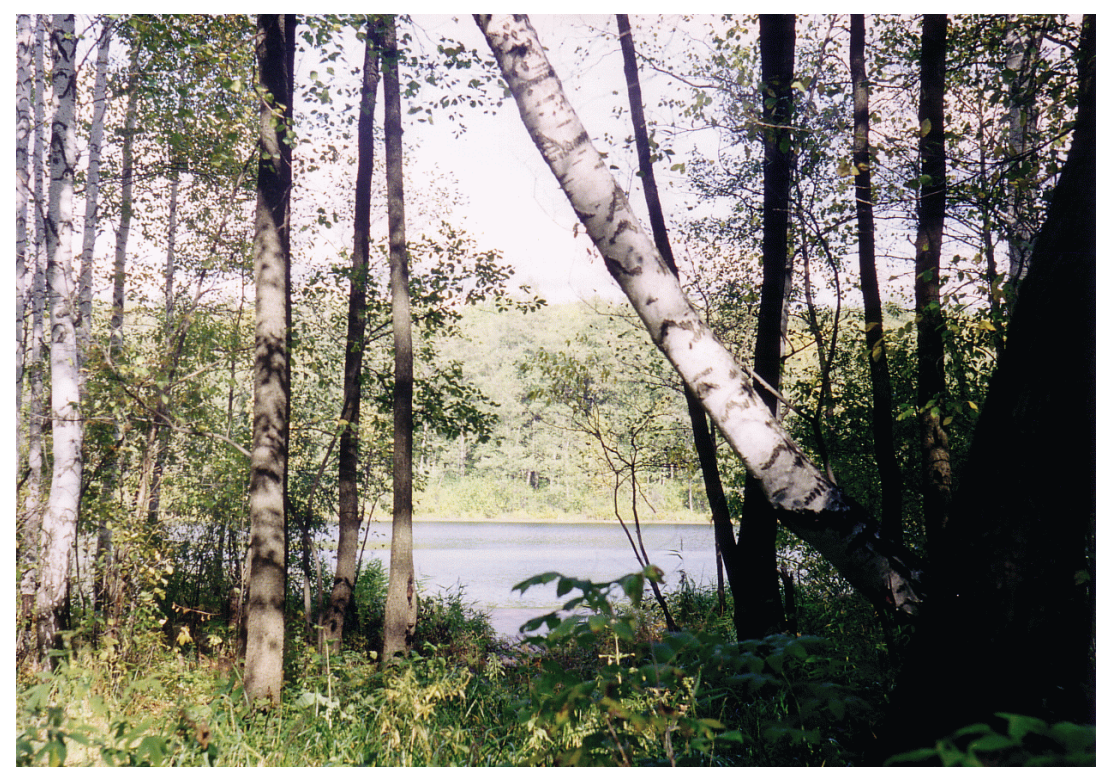

Рис. 1. Озеро Святовское (Тамбовская область, окрестности г. Тамбов)

Fig. 1. Lake Svyatovskoye (Tambov Region, vicinity of Tambov)

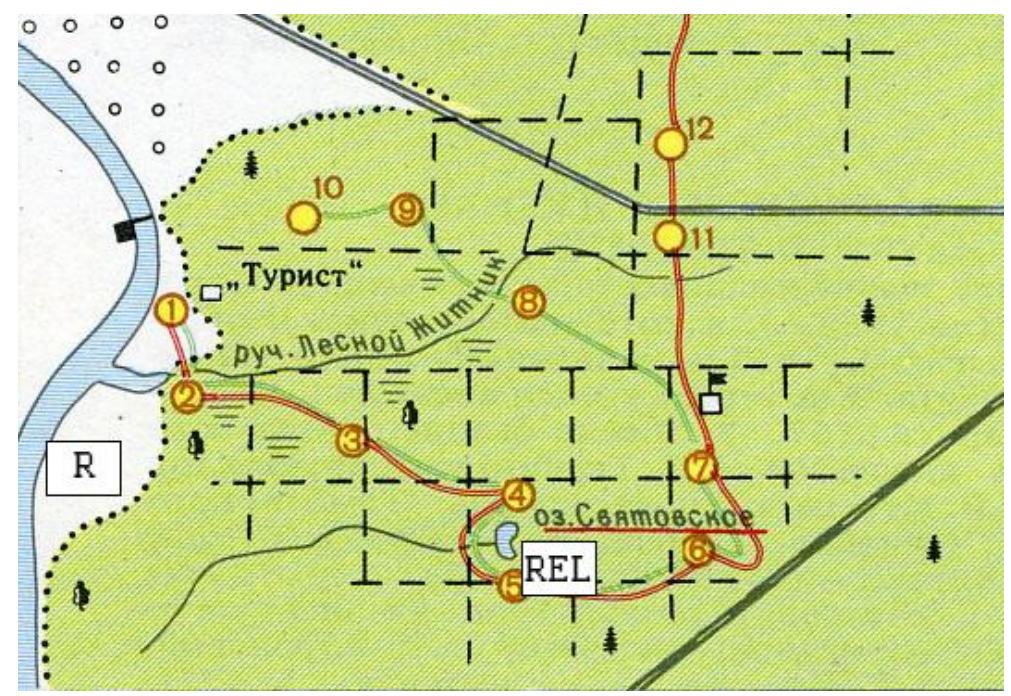

Рис. 2. Изменение популяционной системы зеленых лягушек в озере Святовское

(Тамбовская область, окрестности г. Тамбов)

Fig. 2. Change in population system of green frogs in Svyatovskoye Lake (Tambov Region, vicinity of Tambov)

В 1982-1992 гг. в озере наблюдалась популяционная система $L E$-типа, в которой прудовая лягушка являлась доминирующим по численности видом. Озерная лягушка впервые зарегистрирована в озере 23.06.1993, а уже в апреле 1994 г. в нем отмечено большое количество поющих самцов этого вида. С тех пор вплоть до настоящего времени в озере Святовское представлена популяционная система $R E L$-типа с численным преобладанием двух родительских видов зеленых лягушек (P. ridibundus и P. lessonae). Судя по 
всему, продвижение озерной лягушки из реки в озеро происходило по руслу ручья и, возможно, по низким местам поймы реки Цна и ручья.

2. Тамбовская область, Тамбовский район, Галдымское лесничество, старица и пойменные озера реки Цна и водоемы Галдымского торфяного болота (рис. 3,4 ).

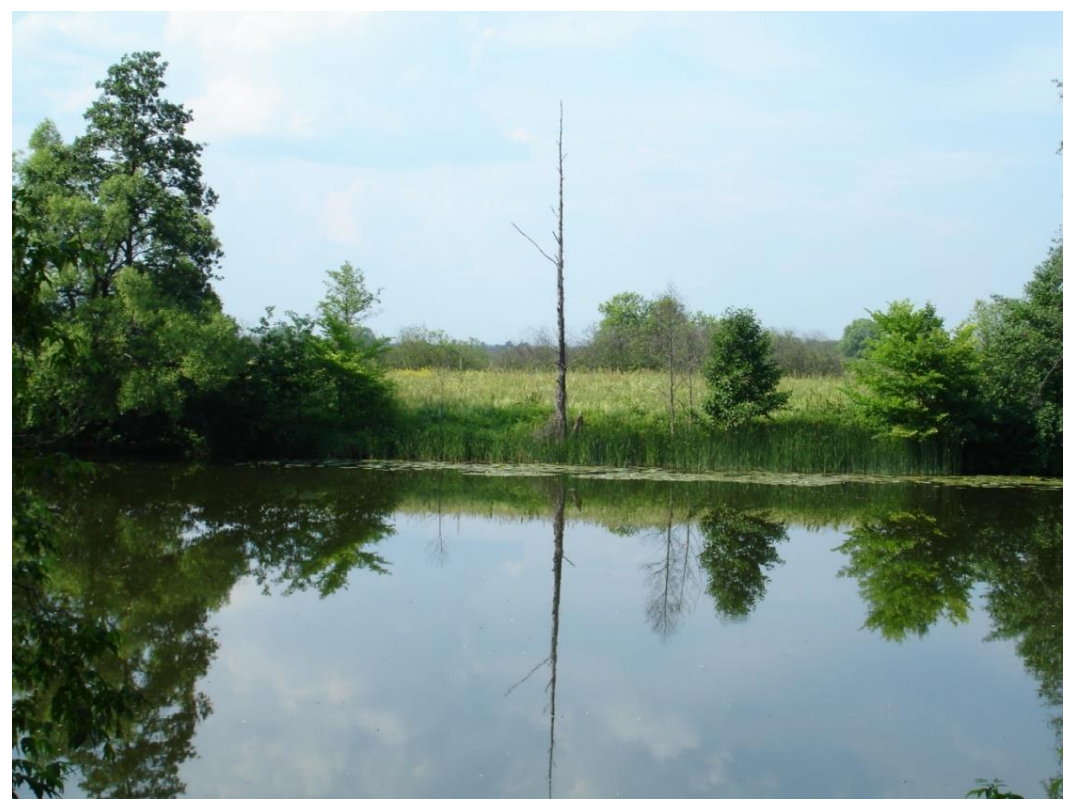

Рис. 3. Старица реки Цна в Галдымском лесничестве (Тамбовская область, Тамбовский район) Fig. 3. Old riverbed of Tsna River in Galdymskoye Forestry (Tambov Region, Tambovskiy District)

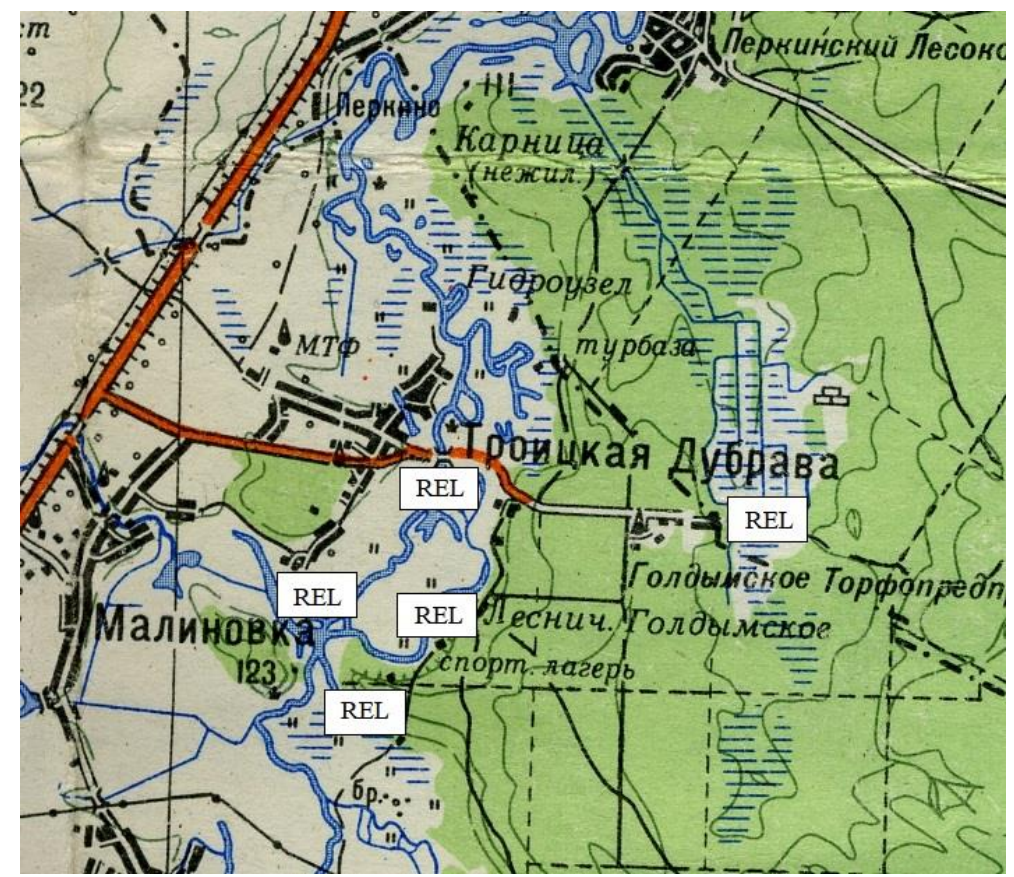

Рис. 4. Изменение популяционной системы зеленых лягушек в Галдымском лесничестве (Тамбовская область, Тамбовский район)

Fig. 4. Change in population system of green frogs in Galdymskoye Forestry (Tambov Region, Tambovskiy District)

Согласно наблюдениям 1983-1986 и 1989-1996 гг., здесь была представлена популяционная система $L E$-типа, в которой почти абсолютно доминировала прудовая лягушка, и лишь изредка встречались единичные особи P. esculentus. Первые озерные лягушки (два экземпляра) были отмечены 16.07.1997 в искусственном водоеме, расположенном вблизи 
конторы Галдымского торфопредприятия. Начиная с 1998 года, P. ridibundus стала регистрироваться в старице реки Цна напротив студенческого лагеря «Молодежный» и в небольших пойменных озерах. По-видимому, озерная лягушка проникла сюда из основного русла реки Цна, где этот вид достаточно обычен в популяционной системе REL-типа, расселяясь вдоль старицы и/или по влажной пойме. Как и в основном русле реки, здесь сформировалась популяционная система $R E L$-типа.

3. Тамбовская область, Моршанский, Сосновский, Пичаевский и Бондарский районы, водоемы Цнинского лесного массива (рис. 5, 6). Изучение комплекса зеленых лягушек на этой обширной территории началось в 1986 году и проходило на разных участках в различные сроки. В целом для лесных участков рек (Керша и Хмелина), ручьев (Нигаляй, Веникляй, Жужляй) и связанных с ними пойменных водоемов в начальный период нашей работы были характерны популяционные системы $L$ - и $L E$-типа (последние - с резким преобладанием прудовой лягушки). Они и остались таковыми до сих пор в водоемах, наиболее удаленных от лесной опушки и русла реки Цна. Так, чистые популяции P. lessonae сохранились в озере Журавлиное и других водоемах, расположенных между бывшим кордоном Николаевский и так называемой «лесной госдорогой» (Сосновский район, Семикинское лесничество). Популяционная система $L E$-типа существует на запруженных участках безымянного ручья в бывшем поселке Гагаринское лесничество (Пичаевский район) и ручья Жужляй в Кривополянском лесничестве (Бондарский район). В то же время озерная лягушка активно расселяется из русла реки Цна, где представлена популяционная система $R E L$-типа, вдоль наиболее значительных водотоков Цнинского лесного массива (рек Керша и Хмелина). Так, уже 15.07.1986 молодой экземпляр этого вида пойман на берегу реки Керша у бывшего кордона Коровий Брод (Моршанский район). В 2004 году (24 апреля и с 10 по16 июня) голоса самцов P. ridibundus звучали в пруду в бывшем поселке Перкинский 2-й (Бондарский район, Кривополянское лесничество). Наконец, 13.06.2007 брачная вокализация самцов озерной лягушки отмечена в реке Керша в урочище Крутые Бережки (Бондарский район, Кривополянское лесничество).

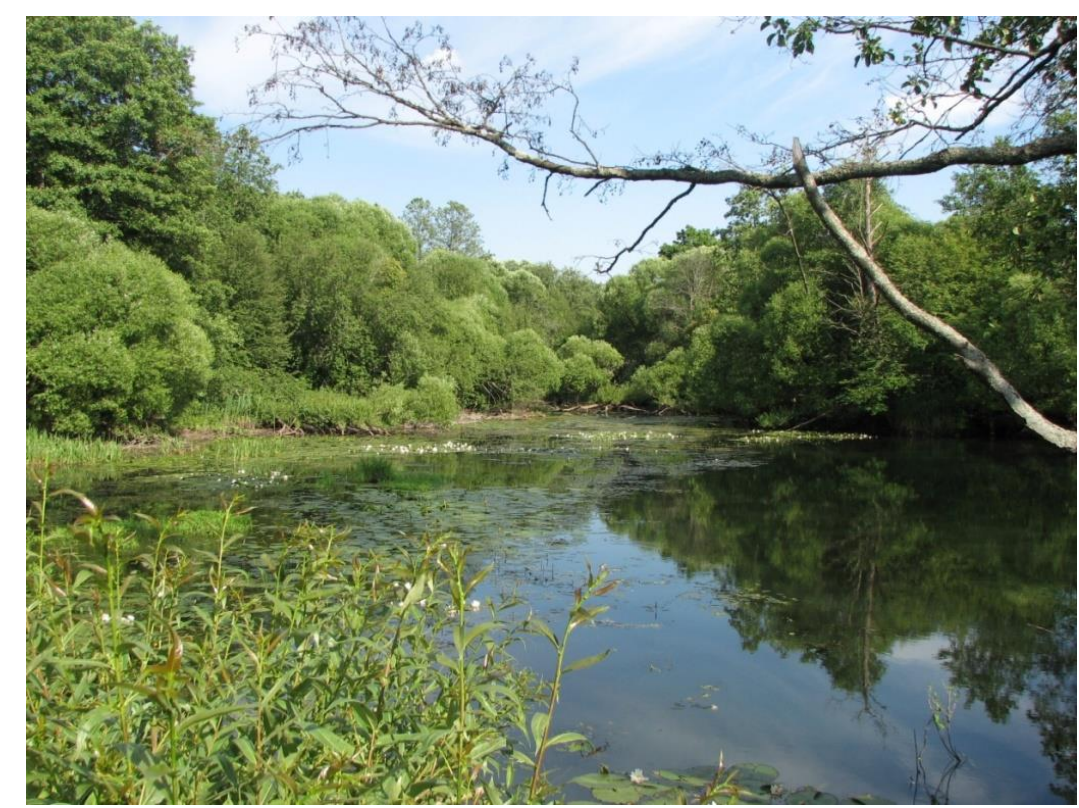

Рис. 5. Река Керша (Тамбовская область, Сосновский район)

Fig. 5. Kyorsha River (Tambov Region, Sosnovskiy District) 


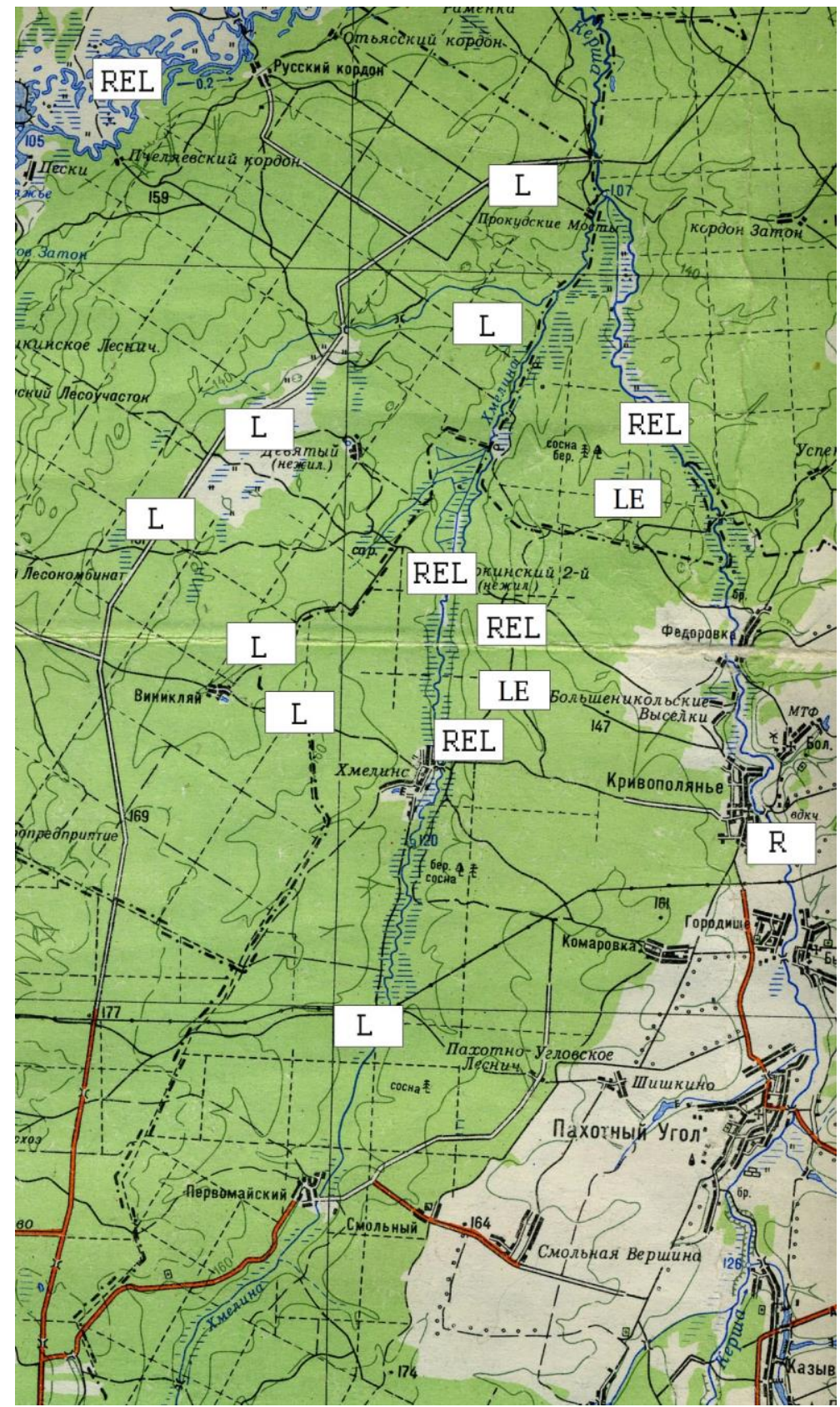

Рис. 6. Изменение популяционной системы зеленых лягушек

в водоемах Цнинского лесного массива (Тамбовская область, Моршанский, Сосновский, Пичаевский и Бондарский районы)

Fig. 6. Change in population system of green frogs in reservoirs of Tsninskiy forest area

(Tambov Region, Morshanskiy, Sosnovskiy, Pichayevskiy and Bondarskiy Districts)

4. Харьковская область, Змиевский район, Иськов пруд (рис. 7). Согласно материалам В.И. Ведмедери [1984], в 1960-1970-е годы для этого водоема была характерна «чистая» популяция P. esculentus. По нашим сведениям, такая же картина имела место и в середине 1990-х годов [Лада, 1998]. В конце 1990-х гг. была разрушена плотина, поддерживающая уровень воды в пруде, в результате ниже образовались водоемы. Они стали стациями переживания для особей озерной лягушки, расселяющихся из ближайших мест своего обитания - лежащих к северу и западу прудов в окрестностях сел Жадановка и Беспаловка, а также расположенной к востоку поймы реки Северский Донец. В результате образовалась популяционная система $R E$-типа (рис. 8 ). 


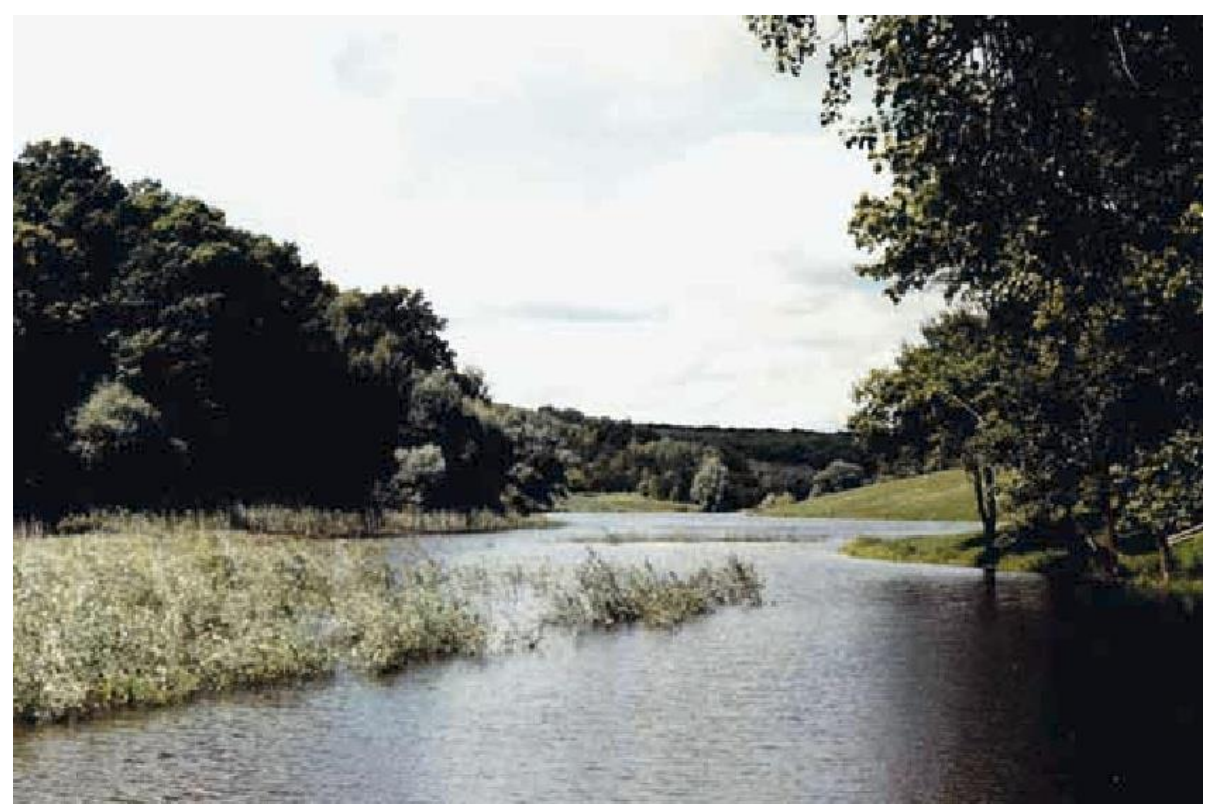

Рис. 7. Иськов пруд (Харьковская область, Змиевский район)

Fig. 7. Iskov Pond (Kharkiv Region, Zmiyovskiy District)

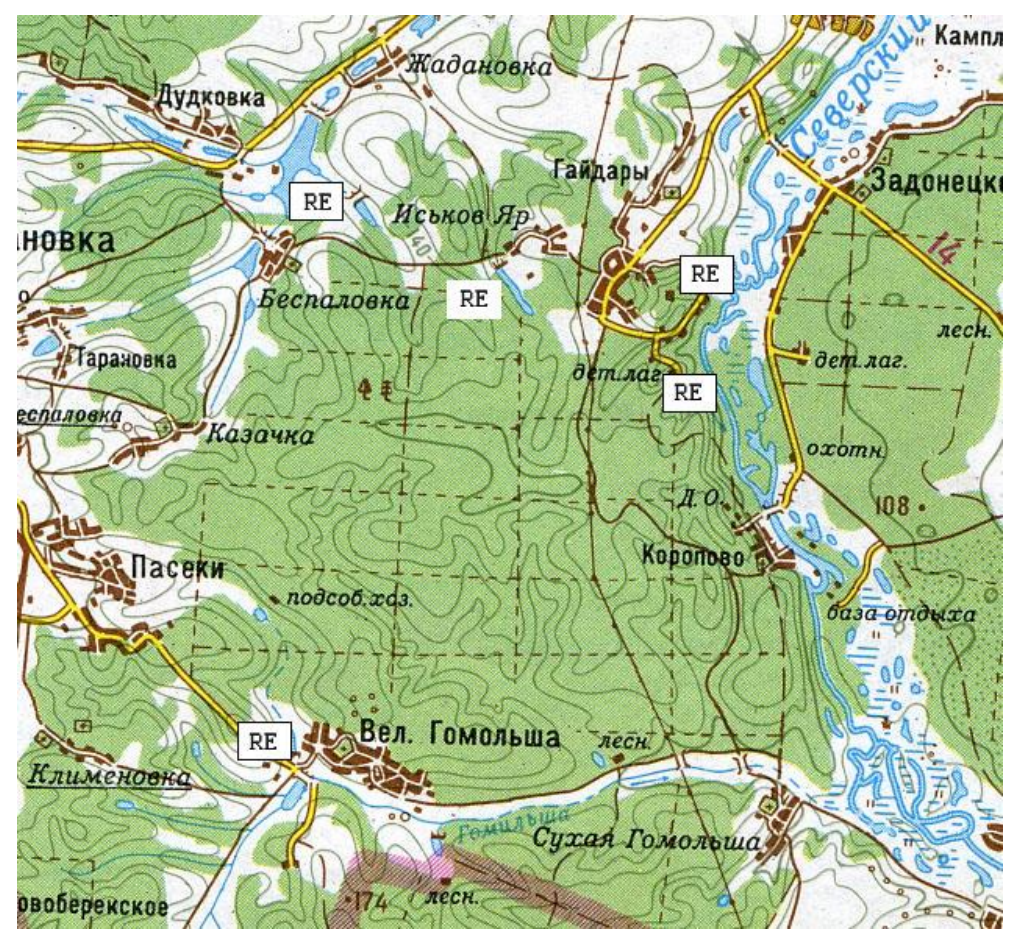

Рис. 8. Изменение популяционной системы зеленых лягушек в Иськовом пруде (Харьковская область, Змиевский район)

Fig. 8. Change in population system of green frogs in Iskov Pond (Kharkiv Region, Zmiyovskiy District)

\section{Заключение}

Таким образом, в ходе многолетних наблюдений в ряде мест зарегистрированы изменения типов популяционных систем зеленых лягушек. Основной причиной этого явилась высокая способность к расселению P. ridibundus. Используя речные русла или естественные понижения рельефа с повышенной влажностью местообитаний, этот вид активно проникает в лесные массивы, в которых заселяет непроточные или слабопроточные водоемы естественного или антропогенного происхождения. Этому в ряде случаев способ- 
ствуют изменяющиеся условия внешней среды - изреживание лесных массивов в результате интенсивных лесозаготовительных работ и появление новых водоемов на пути естественного расселения молодняка амфибий.

\section{Список литературы}

1. Боркин Л.Я., Безман-Мосейко О.С., Мазепа Г.А., Зиненко А.И., Коршунов А.В., Лада Г.А., Шабанов Д.А., Литвинчук С.Н., Розанов Ю.М. 2008. О южной границе распространения гибридной Rana esculenta (Ranidae, Anura, Amphibia) на территории Украины и Молдовы: данные проточной ДНК-цитометрии. Праці Українського герпетологічного товариства, 1: 5-10.

2. Боркин Л.Я., Виноградов А.Е., Розанов Ю.М., Цауне И.А. 1987. Полуклональное наследование в гибридогенном комплексе Rana esculenta: доказательство методом проточной ДНК-цитометрии. Доклады АН СССР, 295 (5): 1261-1264.

3. Боркин Л.Я., Зиненко А.И., Коршунов А.В., Лада Г.А., Литвинчук С.Н., Розанов Ю.М., Шабанов Д.А. 2005. Массовая полиплоидия в гибридогенном комплексе Rana esculenta (Ranidae, Anura, Amphibia) на востоке Украины. B кн.: Матеріали першої конференції Українського герпетологічного товариства (Кіїв, 10-12 жовтня 2005 р.). Кіїв, Зоомузей ННПМ НАН України: $23-26$.

4. Боркин Л.Я., Литвинчук С.Н., Розанов Ю.М., Лада Г.А., Ручин А.Б., Файзулин А.И., Замалетдинов Р.И. 2003. Гибридогенный комплекс Rana esculenta: существует ли волжский парадокс? $B$ кн.: Третья конференция герпетологов Поволжья. Материалы региональной конференции (Тольятти, 5-7 февраля 2003 г.). Тольятти, ИЭВБ РАН: 7-12.

5. Ведмедеря В.И. 1984. Некоторые данные о лягушках рода Rana в Харьковской области (по материалам Музея природы ХГУ). Вестник Харьковского университета, 262: 99-101.

6. Лада Г.А. 1995. Среднеевропейские зеленые лягушки (гибридогенный комплекс Rana esculenta): введение в проблему. $B$ кн.: Флора и фауна Черноземья. Тамбов, Тамбовский государственный университет имени Г.Р. Державина: 88-109.

7. Лада Г.А. 1998. О необходимости сохранения уникальных «чистых» популяций диплоидной съедобной лягушки (Rana esculenta Linnaeus, 1758) в Белгородской и Харьковской областях. $B$ кн.: Проблемы охраны и рационального использования природных экосистем и биологических ресурсов. Материалы Всероссийской научно-практической конференции, посвященной 125-летию И.И. Спрыгина (Пенза, 18-20 мая 1998 г.). Пенза, Приволжский Дом знаний: 333-335.

8. Лада Г.А. 2001. Смешанные популяционные системы $R E L$-типа зеленых лягушек (Rana esculenta complex) в пойменных биогеоценозах реки Воронеж (Липецкая и Тамбовская области). $B$ кн.: Вопросы герпетологии. Материалы первого съезда Герпетологического общества имени А.М. Никольского (Пущино-на-Оке, 4-7 декабря 2000 г.), Пущино-Москва, МГУ: 154-157.

9. Лада Г.А., Боркин Л.Я., Литвинчук С.Н., Розанов Ю.М. 2009. Видовой состав зеленых лягушек Rana esculenta complex (Amphibia, Ranidae) Днепропетровской области (восточная Украина). Праиі Украӥнського герпетологічного товариства, 2: 37-44.

10. Лада Г.А., Боркин Л.Я., Литвинчук С.Н., Розанов Ю.М. 2011а. Видовой состав и популяционные системы зеленых лягушек, Rana esculenta complex (Amphibia; Anura) бассейна реки Псел. Праці Украӥнського герпетологічного товариства, 3: 76-83.

11. Лада Г.А., Боркин Л.Я., Литвинчук С.Н., Розанов Ю.М. 2011б. Типы популяционных систем зеленых лягушек (Rana esculenta complex) на территории Русской равнины. B кн.: Вопросы герпетологии. Материалы IV съезда Герпетологического общества имени А.М. Никольского (Казань, 12-17 октября 2009 г.). СПб., Русская коллекция: 142-148.

12. Ручин А.Б., Боркин Л.Я., Лада Г.А., Литвинчук С.Н., Розанов Ю.М., Рыжов М.К. 2005. Морфологическая изменчивость, размер генома и популяционные системы зеленых лягушек (Rana esculenta complex) Мордовии. Бюллетень МОИП. Отдел биологический, 110 (2): 3-10.

13. Цауне И.А., Боркин Л.Я. 1993. Новый вариант однополо-бисексуальных популяционных систем у европейских зеленых лягушек (Rana esculenta complex). B кн.: Гибридизация и проблема вида у позвоночных. М., Издательство Московского университета: 34-52.

14. Berger L. 1967. Embrional and larval development of $F_{1}$ generation of green frogs different combinations. Acta zoologica cracoviensia, 12 (7): 123-160. 
15. Berger L. 1968. Morphology of the $\mathrm{F}_{1}$ generation of various crosses within Rana esculenta complex. Acta zoologica cracoviensia, 13 (13): 301-324.

16. Berger L., Uzzell T., Hotz H. 1998. Sex determination and sex ratios in western Palearctic water frogs: XX and XY female hybrids in the Pannonian Basin? Proceedings of the Academy of Natural Sciences of Philadelphia, 140 (1): 220-239.

17. Biriuk O.V., Shabanov D.A., Korshunov A.V., Borkin L.J., Lada G.A., Pasynkova R.A., Rosanov J.M., Litvinchuk S.N. 2016. Gamete production patterns and mating systems in water frogs of the hybridogenetic Pelophylax esculentus complex in north-eastern Ukraine. Journal of Zoological Systematics and Evolutionary Research, 54 (3): 215-225.

18. Borkin L.J., Korshunov A.V., Lada G.A., Litvinchuk S.N., Rosanov J.M., Shabanov D.A., Zinenko A.I. 2004. Mass occurrence of polyploid green frogs (Rana esculenta complex) in eastern Ukraine. Russian Journal of Herpetology, 11 (3): 203-222.

19. Borkin L.J., Lada G.A., Litvinchuk S.N., Melnikov D.A., Rosanov J.M. 2006. The first record of mass tryploidy in hybridogenetic green frog Rana esculenta in Russia (Rostov oblast'). Russian Journal of Herpetology, 13 (1): 77-82.

20. Günther R. 1975. Zum naturlichem Vorkommen und zur Morphologie triploider Teichfrösche, "Rana esculenta" L., in der DDR (Anura, Ranidae). Mitteilungen aus dem Zoologischen Museum in Berlin, 51 (1): 145-158.

21. Lada G.A. 1999. Pure diploid hybridogenetic populations of $R$. kl. esculenta (Linnaeus, 1758) in Central Russia and Eastern Ukraine. In: Genetics, Systematics and Ecology of Western Palearctic Water frogs. Abstracts of Third International Symposium (Berlin, 11-15 October 1999). Berlin, Museum of Natural History: 11.

22. Lada G.A., Borkin L.Y., Vinogradov A.E. 1995. Distribution, population systems and reproductive behaviour of green frogs (hybridogenetic Rana esculenta complex) in the Central Chernozem Territory of Russia. Russian Journal of Herpetology, 2 (1): 46-57.

23. Morozov-Leonov S.J., Mezhzherin S.V., Kurtyak T.T. 2003. The genetic structure of the unisex hybrid Rana esculenta complex populations in the Transcarpathians lowlands. Tsitology and genetics, 1: 43-47.

24. Tunner H.G. 1974. Die Klonale Struktur einer Wasserfröschpopulation. Zeitschrift für zoologische Systematik und Evolutionsforschung, 12 (4): 309-314.

25. Uzzell T., Berger L. 1975. Electrophoretic phenotypes of Rana ridibunda, Rana lessonae and their hybridogenetic associate Rana esculenta. Proceedings of the Academy of Natural Sciences of Philadelphia, 127: 13-24.

26. Vinogradov A.E., Borkin L.J., Günther R., Rosanov J.M. 1990. Genome elimination in diploid and triploid Rana esculenta males: cytological evidence from DNA flow cytometry. Genome, 33 (5): 619-627.

\section{References}

1. Borkin L.J., Bezman-Moseiko O.S., Mazepa G.A., Zinenko A.I., Korshunov A.V., Lada G.A., Shabanov D.A., Litvinchuk S.N., Rozanov J.M. 2008. On the southern limit of range of hybrid Rana esculenta (Ranidae, Anura, Amphibia) in Ukraine and Moldova: DNA flow cytometry evidence. Proceedings of the Ukrainian Herpetological Society, 1: 5-10. (in Russian)

2. Borkin L.J., Vinogradov A.T., Rozanov J.M., Caune I.A. 1987. Hemiclonal inheritance in the hybridogenetic Rana esculenta complex: evidence by method of DNA flow cytometry. Proceedings of the Academy of Sciences of the USSR, 295 (5): 1261-1264. (in Russian)

3. Borkin L.J., Zinenko A.I., Korshunov A.V., Lada G.A., Litvinchuk S.N., Rozanov J.M., Shabanov D.A. 2005. Mass polyploidy in the hybridogenetic Rana esculenta complex (Ranidae, Anura, Amphibia) in the East of Ukraine. In: Proceedings of the First conference of the Ukrainian Herpetological Society (Kyiv, 10-12 October 2005). Kyiv, Zoomuseum NMNH NAS of Ukraine: 23-26. (in Russian)

4. Borkin L.J., Litvinchuk S.N., Rozanov J.M., Lada G.A., Ruchin A.B., Faizulin A.I., Zamaletdinov R.I. 2003. Hybridogenetic complex Rana esculenta: would exist "Volga paradox"? In: Third conference of Herpetologists of the Volga Region. Materials of regional conference (Togliatti, 57 February 2003). Togliatti, Institute of Ecology of Volga Basin RAS: 7-12. (in Russian)

5. Vedmederya V.I. 1984. Some data about frogs of the genus Rana in the Kharkiv Region (on the materials of Nature Museum of Kharkiv State University). Bulletin of Kharkiv National University, 262: 99-101. (in Russian) 
6. Lada G.A. 1995. Central European green frogs (hybridogenetic Rana esculenta complex): an introduction to the problem. In: Flora and fauna of the Chernozem region. Tambov, Derzhavin Tambov State University: 88-109. (in Russian)

7. Lada G.A. 1998. On the need to preserve the unique "pure" populations of the diploid edible frog (Rana esculenta Linnaeus, 1758) in the Belgorod and Kharkiv Regions. In: Problems of protection and rational use of natural ecosystems and biological resources. Materials of the All-Russian scientificpractical conference dedicated to the 125th anniversary of I.I. Sprygin (Penza, 18-20 May 1998). Penza, Privolzhsky House of Knowledge: 333-335. (in Russian)

8. Lada G.A. 2001. Mixed REL-population of green frogs (Rana esculenta complex) in floodplain biogeocenoses of the Voronezh River (Lipetskaya and Tambovskaya Provinces). In: The problems of Herpetology. Materials of the First meeting of the Nikolsky Herpetological Society (Pushchino-na-Oke, 4-7 December, 2000). Pushchino-Moscow, Moscow University: 154-157. (in Russian)

9. Lada G.A., Borkin L.Y., Litvinchuk S.N., Rozanov J.M. 2009. Green frog Rana esculenta complex (Amphibia, Ranidae) composition in Dnepropetrovsk Province (Eastern Ukraine). Proceedings of the Ukrainian Herpetological Society, 2: 37-44. (in Russian)

10. Lada G.A., Borkin L.Y., Litvinchuk S.N., Rozanov J.M. 2011a. Species composition and population systems of green frogs, Rana esculenta complex (Amphibia; Anura) in the Psyol' River Drainage. Proceedings of the Ukrainian Herpetological Society, 3: 76-83. (in Russian)

11. Lada G.A., Borkin L.Y., Litvinchuk S.N., Rozanov J.M. 2011б. Types of population systems of green frogs (Rana esculenta complex) on Russian Plain territory. In: The problems of Herpetology. Materials of the Fourth meeting of the Nikolsky Herpetological Society (Kazan, 12-17 October 2009). Saint-Petersburg, Russian collection: 142-148. (in Russian)

12. Ruchin A.B., Borkin L.Y., Lada G.A., Litvinchuk S.N., Rozanov J.M., Ryzhov M.K. 2005. Morphological variation, genome size and population systems of the green frog (Rana esculenta complex) of Mordovia. Bulletin of Moscow Society of Naturalists. Biological series, 110 (2): 3-10. (in Russian)

13. Caune I.A., Borkin L.J. 1993. A new variant of unisexual-bisexual population systems in European green frogs (Rana esculenta complex). In: Hybridization and the problem of species in vertebrates. Moscow, Publishing house of Moscow University: 34-52. (in Russian)

14. Berger L. 1967. Embrional and larval development of $F_{1}$ generation of green frogs different combinations. Acta zoologica cracoviensia, 12 (7): 123-160.

15. Berger L. 1968. Morphology of the $\mathrm{F}_{1}$ generation of various crosses within Rana esculenta complex. Acta zoologica cracoviensia, 13 (13): 301-324.

16. Berger L., Uzzell T., Hotz H. 1998. Sex determination and sex ratios in western Palearctic water frogs: XX and XY female hybrids in the Pannonian Basin? Proceedings of the Academy of Natural Sciences of Philadelphia, 140 (1): 220-239.

17. Biriuk O.V., Shabanov D.A., Korshunov A.V., Borkin L.J., Lada G.A., Pasynkova R.A., Rosanov J.M., Litvinchuk S.N. 2016. Gamete production patterns and mating systems in water frogs of the hybridogenetic Pelophylax esculentus complex in north-eastern Ukraine. Journal of Zoological Systematics and Evolutionary Research, 54 (3): 215-225.

18. Borkin L.J., Korshunov A.V., Lada G.A., Litvinchuk S.N., Rosanov J.M., Shabanov D.A., Zinenko A.I. 2004. Mass occurrence of polyploid green frogs (Rana esculenta complex) in eastern Ukraine. Russian Journal of Herpetology, 11 (3): 203-222.

19. Borkin L.J., Lada G.A., Litvinchuk S.N., Melnikov D.A., Rosanov J.M. 2006. The first record of mass tryploidy in hybridogenetic green frog Rana esculenta in Russia (Rostov oblast'). Russian Journal of Herpetology, 13 (1): 77-82.

20. Günther R. 1975. Zum naturlichem Vorkommen und zur Morphologie triploider Teichfrösche, "Rana esculenta" L., in der DDR (Anura, Ranidae). Mitteilungen aus dem Zoologischen Museum in Berlin, 51 (1): 145-158.

21. Lada G.A. 1999. Pure diploid hybridogenetic populations of $R$. kl. esculenta (Linnaeus, 1758) in Central Russia and Eastern Ukraine. In: Genetics, Systematics and Ecology of Western Palearctic Water frogs. Abstracts of Third International Symposium (Berlin, 11-15 October 1999). Berlin, Museum of Natural History: 11.

22. Lada G.A., Borkin L.Y., Vinogradov A.E. 1995. Distribution, population systems and reproductive behaviour of green frogs (hybridogenetic Rana esculenta complex) in the Central Chernozem Territory of Russia. Russian Journal of Herpetology, 2 (1): 46-57. 
23. Morozov-Leonov S.J., Mezhzherin S.V., Kurtyak T.T. 2003. The genetic structure of the unisex hybrid Rana esculenta complex populations in the Transcarpathians lowlands. Tsitology and genetics, 1: 43-47.

24. Tunner H.G. 1974. Die Klonale Struktur einer Wasserfröschpopulation. Zeitschrift für zoologische Systematik und Evolutionsforschung, 12 (4): 309-314.

25. Uzzell T., Berger L. 1975. Electrophoretic phenotypes of Rana ridibunda, Rana lessonae and their hybridogenetic associate Rana esculenta. Proceedings of the Academy of Natural Sciences of Philadelphia, 127: 13-24.

26. Vinogradov A.E., Borkin L.J., Günther R., Rosanov J.M. 1990. Genome elimination in diploid and triploid Rana esculenta males: cytological evidence from DNA flow cytometry. Genome, 33 (5): 619-627.

\section{ИНФОРМАЦИЯ ОБ АВТОРЕ}

Лада Георгий Аркадьевич, доктор биологических наук, доцент, профессор кафедры биологии и биотехнологии Тамбовского государственного университета имени Г.Р. Державина, г. Тамбов, Россия

\section{INFORMATION ABOUT THE AUTHOR}

Georgiy A. Lada, Doctor of Biological Sciences, Associate Professor, Professor of the Department of Biology and Biotechnology of Derzhavin Tambov State University, Tambov, Russia 